Notes and Comments

\title{
Distribution extension of Curimatella immaculata (Fernández-Yépez, 1948) Curimatidae, Amazon, Brazil
}

\author{
L. P. de Oliveiraa,b* (D) F. Corrêac (D), R. S. da Silvad (D) and L. J. S. Vieira ${ }^{\mathrm{a}, \mathrm{b}}$ (D) \\ aniversidade Federal do Acre - UFAC, Laboratório de Ictiologia e Ecologia Aquática, Campus Rio Branco, Rio Branco, AC, Brasil \\ ${ }^{\mathrm{b}}$ Universidade Federal do Acre - UFAC, Programa de Pós-Graduação em Ecologia e Manejo de Recursos Naturais, Campus Rio Branco, Rio Branco, AC, Brasil \\ ' Universidade do Estado de Mato Grosso - UNEMAT, Programa de Pós-graduação em Ecologia e Conservação, Nova Xavantina, MT, Brasil \\ dUniversidade Federal do Pará - UFPA, Programa de Pós-graduação em Zoologia, Campus Básico, Belém, Pará, Brasil
}

Among the hydrographic basins of the Neotropical region, the Amazon basin presents the richest freshwater fish fauna in the world, consisting of 57 families, 525 genera and 2411 valid species (Reis et al., 2016). New species are described each year, and the estimates exceed 9,000 species (Reis et al., 2016; Birindelli and Sidlauskas, 2018), for the Neotropical region. For the many water resources that form the Amazon basin, the Acre river is a mediumsized watercourse, by the standards of the Amazon basin, running $1190 \mathrm{~km}$ from its source, in Peru, to its confluence with the Purus river in the Brazilian state of Amazonas, first passing through Bolivia and then the state of Acre, Brazil (Silva et al., 2020). For the many water resources that form the Acre river basin, the hydrographic basin Quinoá stream (HBQS), a tributary of the right bank, is an important ecosystem that must be conserved for ecological maintenance and balance (Acre, 2012; Corrêa et al., 2018). The family Curimatidae has eight genus and 115 described species (Fricke et al., 2020), five of which belong to the genus Curimatella (Eigenmann and Eigenmann, 1889), where they live in South America, east and south Cordilheira of Andes (Vari, 1992). The genus Curimatella is distinctive among curimatids by having a significant concentration of small scales covering the middle rays of the both lobes of caudal fins; the patches extend over most of these rays (Vari, 1992). In general, species of the Curimatella feed on sediments/ debris (Dary et al., 2017; Santos et al., 2020), some fish of this genus are used for food in riverside communities in the Amazon (Begossi et al., 2019). This paper documents the first record and distribution expansion of Curimatella immaculata (Fernández-Yépez, 1948) in the Acre River hydrographic basin, Acre, whit highlighting the importance of studies for the region and the better knowledge on its ichthyofauna. The individuals were collected in the HBQS (Figure 1) (31 $\left.{ }^{\circ} 6^{\prime} 51^{\prime \prime} \mathrm{S} / 50^{\circ} 51^{\prime} 16.71^{\prime \prime} \mathrm{W}\right)$, that is characterized by anthropogenic environments (dams, degradation of ciliary forest by pasture, accumulation of garbage and sewage from residences), and presents forest fragments in different degrees of conservation, with 1st, 2nd, and 3rd order stream (Acre, 2012; Corrêa et al., 2018). We conducted the fish sampling bi-monthly during a two- year period, between August/2016 and July/2018 (SISBIO no \#11778), according to Corrêa et al. (2015), using the following sampling artifacts: a) trawl of $5 \mathrm{~m}$ of length, $2.25 \mathrm{~m}$ of height, and $5 \mathrm{~mm}$ mesh between adjacent nodes, performing three swipes at each site per collection; b) two dip nets with $5 \mathrm{~mm}$ mesh, $30 \mathrm{~cm}$ of width, and $50 \mathrm{~cm}$ of length with an effort of 30 minutes of activity; and c) two sieves made of $5 \mathrm{~mm}$ mesh, $50 \mathrm{~cm}$ of width, and $80 \mathrm{~cm}$ of length, using a 30 minute effort at each site per collection. After sampling, we euthanized the individuals using Eugenol (CONCEA, 2013), subsequently, the collected fish were stored in plastic bags, labeled and set at $5 \%$ formalin and taken to the laboratory, transferring them to $70 \%$ alcohol. In the laboratory, we measured the total weight (TW, g) in grams and, according to Vari (1992), took the following morphometric measurements in millimeters ( $\mathrm{mm})$ : total length, standard length, head height, body height, tail peduncle height, head length, anal fin length, dorsal fin length, pectoral fin length, pelvic fin length, tail fin length, pre-anal distance, pre-dorsal distance, pre-pectoral distance, pre-pelvic distance, muzzle length, muzzle width, orbital diameter, interorbital distance, and pre-nasal distance. We deposited the fish at the collection of Laboratório de Ictiologia e Ecologia Aquática, Universidade Federal do Acre (MUFAC-IC 993). We collected five individuals of C. immaculata (Figure 2), which presented a mean total length of $79.6 \pm 4.63 \mathrm{~mm}$ and a mean total weight of 7.1 $\pm 1.78 \mathrm{~g}$. The morphometric measures corroborated with the data obtained by Vari (1992) for C. immaculata (Table 1). C. immaculata is distinguished from other species of the genus mainly due to the following characteristics: of 29 to 33 scales from the lateral line to the hypural region, 5 or 6 scales in a transverse series from the lateral line to the origin of the dorsal fin, 31 to 33 vertebrae and absence of dark spot on the medial lateral surface of the caudal peduncle (Vari, 1992). In this study, we recorded the distribution of the specie in more than $400 \mathrm{~km}$ of the records to Acre state, considering that there are records for the specie in the Tarauacá River (Vari, 1992) and in the upper Juruá River (Begossi et al., 2019).C. immaculata is recorded, for example in Madeira River, Rondônia state (more than 700 km from

*e-mail: lucspires10@gmail.com

Received: April 13, 2020 - Accepted: July 13, 2020

This is an Open Access article distributed under the terms of the Creative Commons Attribution License, which permits unrestricted use, distribution, and reproduction in any medium, provided the original work is properly cited. 


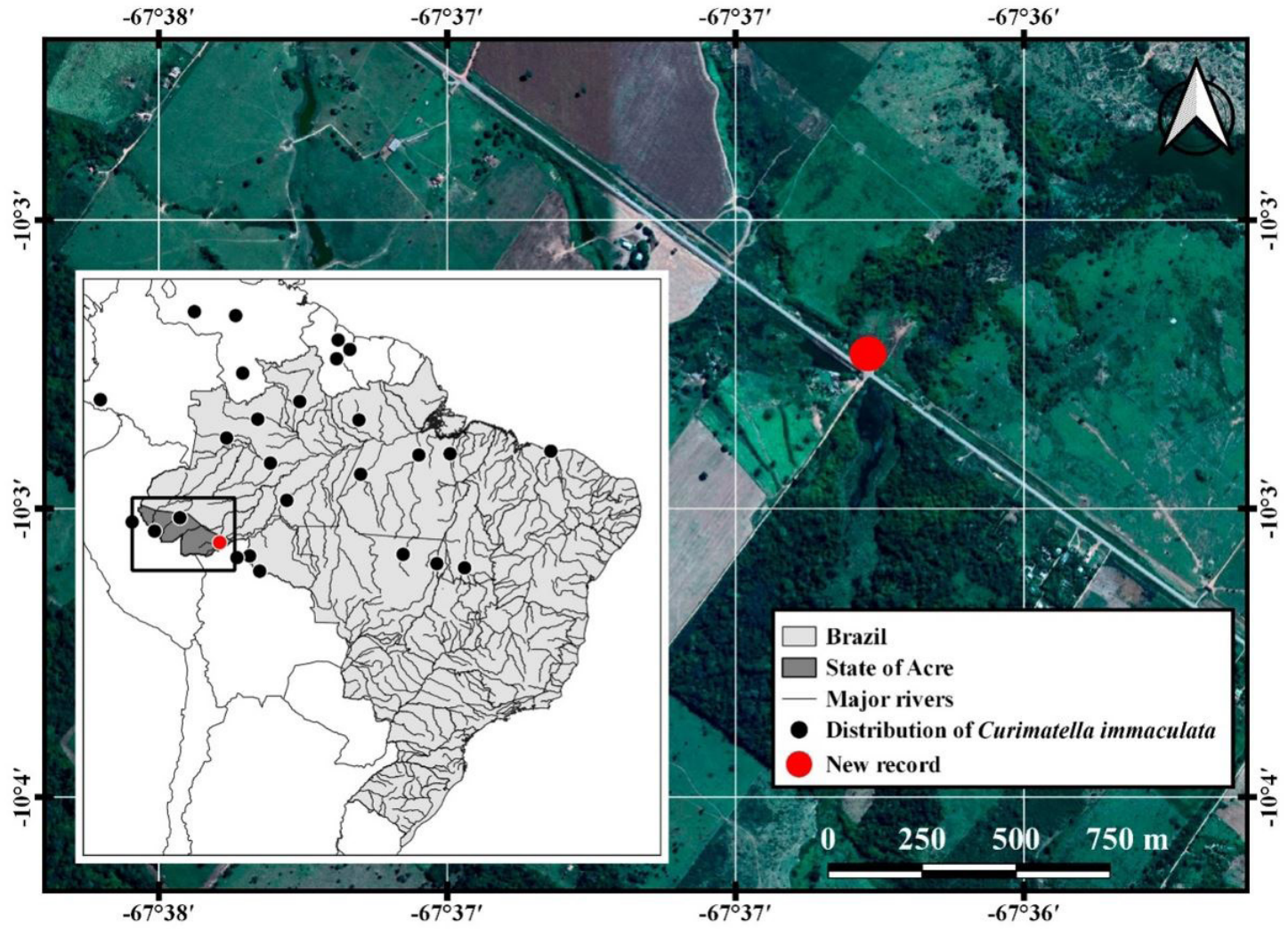

Figure 1. Distribution of Curimatella immaculata, where the black dots represent records of the specie (Vari, 1992; Dagosta and de Pinna, 2019), and the red dot indicates the new area of occurrence of the specie in the hydrographic basin Quinoá stream. (Figure by Ronaldo Souza da Silva).

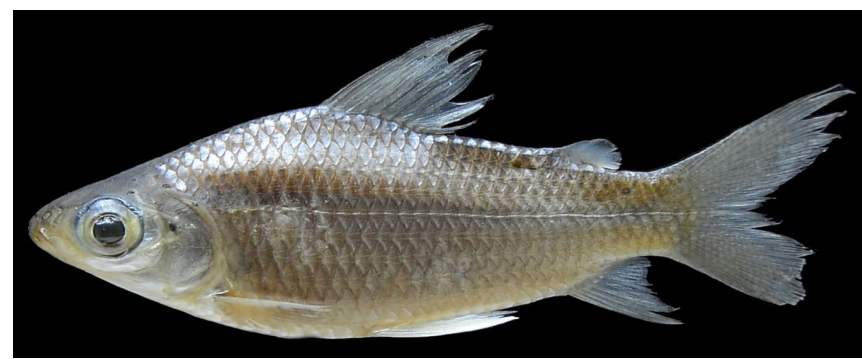

Figure 2. Curimatella immaculata collected in the hydrographic basin Quinoá stream, State of Acre, Brazil (Picture by Fabiano Corrêa).

Table 1. Morphometric measures of five Curimatella immaculata individuals captured from the hydrographic basin Quinoá stream, Acre, Brazil. SD = standard deviation.

\begin{tabular}{lcccc}
\hline & Low & High & Mean & SD \\
\hline Total weight & 5.5 & 10.4 & 7.1 & 1.8 \\
Total length & 75.0 & 87.0 & 79.6 & 4.6 \\
Standard length & 57.0 & 67.0 & 60.8 & 4.0 \\
\hline & \multicolumn{4}{c}{ Percentage of the standard length } \\
\hline Head height & 21.2 & 21.7 & 21.6 & 0.2 \\
Body height & 35.1 & 46.6 & 39.2 & 4.0 \\
Height of the tail peduncle & 12.5 & 14.0 & 13.5 & 0.6 \\
Head length & 28.5 & 32.0 & 30.4 & 1.5 \\
Anal fin length & 14.1 & 19.6 & 17.2 & 2.0 \\
\hline
\end{tabular}


Table 1. Continued...

\begin{tabular}{lcccc}
\hline & Low & High & Mean & SD \\
\hline Dorsal fin length & 31.4 & 42.4 & 35.0 & 3.8 \\
Pectoral fin length & 17.6 & 19.8 & 18.6 & 0.9 \\
Pelvic fin length & 18.1 & 24.6 & 21.9 & 2.5 \\
Tail fin length & 26.1 & 30.3 & 28.5 & 1.5 \\
Pre-anal distance & 80.3 & 85.1 & 83.4 & 1.9 \\
Pre-dorsal distance & 44.4 & 48.0 & 46.0 & 1.3 \\
Pre-pectoral distance & 29.0 & 30.7 & 29.9 & 0.7 \\
Pre-pelvic distance & 51.2 & 57.6 & 53.8 & 2.2 \\
\hline & & Percentage of the head length & \\
\hline Muzzle length & 22.2 & 33.4 & 28.3 & 3.6 \\
Muzzle width & 30.9 & 35.7 & 33.1 & 1.6 \\
Orbital diameter & 34.0 & 37.7 & 35.6 & 1.3 \\
Interorbital distance & 43.4 & 49.1 & 47.0 & 2.0 \\
Pre-nasal distance & 18.0 & 28.0 & 23.0 & 4.1 \\
\hline
\end{tabular}

HBQS), in lake Janauari, Amazonas (Vari, 1992) and Santa Ana del Yacuma, Bolivia (Hablützel, 2012), more than $1500 \mathrm{~km}$ of sampled locations, among other locations (Figure 1). C. immaculata is currently classified as not Threatened in the Red Book of Endangered Brazilian Fauna and not evaluated by IUCN (ICMBio, 2018). We concluded that, the data registered highlight the relevance of ichthyological studies in little explored hydrographic systems, especially in the southwestern Amazon.

\section{Acknowledgements}

The members of the Laboratório de Ictiologia e Ecologia Aquática of Universidade Federal do Acre, CNPq for the scholarship granted (number: 123405/2018-1), and the National Postgraduate Program of CAPES.

\section{References}

ACRE. SECRETARIA DE ESTADO DE MEIO AMBIENTE - SEMA, 2012. Plano estadual de recursos hídricos do Acre. Rio Branco: SEMA. 243 p.

BEGOSSI, A., SALIVONCHYK, S.V., HALLWASS, G., HANAZAKI, N., LOPES, P.F.M., SILVANO, R.A.M., DUMARESQ, D. and PITTOCK, J., 2019. Fish consumption on the Amazon: a review of biodiversity, hydropower and food security issues. Brazilian Journal of Biology = Revista Brasleira de Biologia, vol. 79, no. 2, pp. 345-357. http://dx.doi.org/10.1590/1519-6984.186572. PMid:30379202.

BIRINDELLI, J.L.O. and SIDLAUSKAS, B.L., 2018. Preface: how far has Neotropical Ichthyology progressed in twenty years? Neotropical Ichthyology, vol. 16, no. 3, pp. e180128. http:// dx.doi.org/10.1590/1982-0224-20180128.

CONSELHO NACIONAL DE CONTROLE DE EXPERIMENTAÇÃO ANIMAL - CONCEA, 2013. Diretrizes da prática de eutanásia do CONCEA. Brasília: Ministério da Ciência, Tecnologia e Inovação.

CORRÊA, F., OLIVEIRA, E.F., TUCHTENHAGEN, T., POUEY, J. and PIEDRAS, S., 2015. Ichthyofauna of the hydrographic basin of the Chasqueiro Stream (Mirim Lagoon system, southern Brazil): generating subsidies for conservation and management. Biota Neotropica, vol. 15, no. 4, pp. 15113. http://dx.doi.org/10.1590/1676-0611-BN-2015-0006.

CORRÊA, F., SILVA, R.S. and VIEIRA, L.J.S., 2018. Length-weight relationship of three cichlid species in a stream in southwestern Amazon, Brazil. Journal of Applied Ichthyology, vol. 34, no. 5, pp. 1255-1257. http://dx.doi.org/10.1111/jai.13778.

DAGOSTA, F.C.P. and DE PINNA, M., 2019. The fishes of the Amazon: distribution and biogeographical patterns, with a comprehensive list of species. Bulletin of the American Museum of Natural History, vol. 2019, no. 431, pp. 1-163. https://doi.org/10.1206/0003-0090.431.1.1.

DARY, E.P., FERREIRA, E., ZUANON, J. and RÖPKE, C.P., 2017. Diet and trophic structure of the fish assemblage in the midcourse of the Teles Pires River, Tapajós River basin, Brazil. Neotropical Ichthyology, vol. 15, no. 4, pp. e160173. http:// dx.doi.org/10.1590/1982-0224-20160173.

FRICKE, R., ESCHMEYER, W.N. and VAN DER LAAN, R., eds, 2020 [viewed 13 April 2020]. Eschmeyer's catalog of fishes [online]. San Francisco: California Academy of Sciences. Available from: http://researcharchive.calacademy.org/ research/ichthyology/catalog/fishcatmain.asp

HABLÜTZEL, P.I., 2012. A preliminary survey of the fish fauna in the vicinity of Santa Ana del Yacuma in Bolivia (río Mamoré drainage). Biota Neotropica, vol. 12, no. 4, pp. 1-10. http:// dx.doi.org/10.1590/S1676-06032012000400017.

Instituto Chico Mendes de Conservação da Biodiversidade ICMBIO, 2018. Livro Vermelho da Fauna Brasileira Ameaçada de Extinção. Brasília: ICMBio/MMA. 492 p., vol. I.

REIS, R.E., ALBERT, J.S., DI DARIO, F., MINCARONE, M.M., PETRY, P. and ROCHA, L.A., 2016. Fish biodiversity and conservation in South America. Journal of Fish Biology, vol. 89, no. 1, pp. 12-47. http://dx.doi.org/10.1111/jfb.13016. PMid:27312713. 
SANTOS, N.C.L., DIAS, R.M., ALVES, D.C., MELO, B.A.R., GANASSIN, M.J.M., GOMES, L.C., SEVERI, W. and ANGELO, A.A., 2020. Trophic and limnological changes in highly fragmented rivers predict the decreasing abundance of detritivorous fish. Ecological Indicators, vol. 110, pp. 105933. http://dx.doi.org/10.1016/j.ecolind.2019.105933.

SILVA, R.S., CORRÊA, F., OLIVEIRA, L.P., GUERRA, V., BARROS, B.S. and VIEIRA, L.J.S., 2020. Ichthyofauna of sandy beaches along the
Acre river, Brazil. Biota Neotropica, vol. 20, no. 2, pp. e20200988. http://dx.doi.org/10.1590/1676-0611-BN-2020-0988.

VARI, R.P., 1992. Systematics of the Neotropical Characiform Genus Curimatella Eigenmann and Eigenmann (Pisces: Ostariophysi), with Summary Comments on the Curimatidae. Washington: Smithsonian Institution Press. http://dx.doi.org/10.5479/ si.00810282.533. 